\title{
RELATIONSHIP BETWEEN YIELD POTENTIAL AND PERCENTAGE YIELD DECLINE CAUSED BY THE ROOT- KNOT NEMATODE, Meloidogyne javanica FOR SOME SUGAR BEET VARIETIES SOWN IN WEST NUBARIYA REGION \\ Gohar, I. M. A. ; K.M. Agami and M. S. M. Aly \\ Sugar Crops Res. Inst., Agric. Res. Center, 12619, Giza, Egypt.
}

\begin{abstract}
Four experiments were carried out in West Nubariya region ; two of them were field trials and the other two were outdoor pots trials throughout seasons of 2009/ 2010 and 2010/ 2011 that to evaluate a collection of M. javanica susceptible sugar beet varietiess for differing levels of yield decline (tolerance), their tolerance to parasitism by this nematode. If nematode tolerant (low yield decline) but susceptible (high nematode reproduction) sugar beet varieties can be identified, they could be grown rather than intolerant varieties to reduce yield loss. The yield potential and percentage yield loss to $M$. javanica were measured in 15 sugar beet varieties in 2009/ 2010 and 2010/ 2011 by comparing yields in Dazomet 98\% (Methyl Isothiocyanate) - fumigated and nonfumigated plots. The percentage yield decline caused by M. javanica differed among sugar beet varieties in 2009/2010 and 2010/ 2011. Yield decline ranged from 32.2 to $46.2 \%$ in 2009/ 2010 and from 26.3 to $34.5 \%$ in 2010/2011. Though significant levels of tolerance were measured in this study, 2 seasons of data on percentage yield decline show that tolerance is not consistently related to specific varieties in the absence of nematode resistance: susceptible varieties did not consistently express tolerance, but moderately resistant varieties did. Thus, it appears unlikely that sugar beet variety selection for tolerance to $M$. javanica can be utilized to minimize yield decline. Regression analysis based on the two seasons of field data revealed a relationship in which percentage yield decline caused by $M$. javanica increased linearly as yield potential increased. The moderately resistant sugar beet varieties, Laser, Romano and Marathon suffered the lowest percentage yield decline and supported the least reproduction in the study so they can be used in the contaminated fields with root-knot nematode through an integrated control measures to maintain good production for sugar beet in such area. Because the absolute and percentage losses to nematodes increase as yield potential increases, nematode management becomes increasingly important and beneficial in sugar beet.

Keywords: varieties, Potential yield, Percentage decline, root yield, sugar yield, rootknot, Meloidogyne javanica, relationship, sugar beet, Regression analysis, Fumigation, Dazomet $98 \%$, eggmass, galls, Nubariya, tolerance.
\end{abstract}

\section{INTRODUCTION}

Today agricultural production systems are under higher economic pressure than ever before. Globalization increases price competition between farmers in different countries and a rising world population requires affordable and safe nutrition. Limited availability of raw materials also will increase the cost of input factors of crop production such as fertilizers, fuel, machinery and plant protection products. Global warming threatens many production areas 
Gohar, I. M. A. et al.

through extreme changes in climatic conditions. Especially pests and pathogens whose damage potential is strongly dependent on environmental factors will gain in importance, because increasing temperatures will allow them to complete more generations per year. Sugar beet is one of the favored hosts of root-knot nematodes. In areas where Meloidogyne spp. occur, they can be a serious problem, and in some cases result in a complete crop failure.

Resistance to root-knot nematode is rare; nematode feeding stimulated formation of giant cells in host tissues, resulting in root galls and protuberances, thus hindering sugar beet growth and limiting production ( $\mathrm{Yu}$, 2003). It is therefore obvious that many control measure modifications and development of new tools for crop health management are needed to maintain present levels of crop production as well as increase overall yields in this ever changing world. No sugar beet varieties are available in the infested sugar beet grown area with a high level of resistance to Meloidogyne spp. and some varieties are featured in some work with a moderate level of resistance. All other available varieties are believed to be susceptible to Meloidogyne spp., but their levels of tolerance have not been quantified. If nematode tolerant but susceptible sugar beet varieties can be identified, then they could be grown to help minimize yield losses.

The objective of this study was to evaluate a collection of sugar beet varieties that are susceptible to $M$. javanica to determine if some are more tolerant than others of parasitism by this nematode through multiple relating of yield potential with midseason nematode densities or/ and with percentage yield decline or/ and with nematode reproduction.

\section{MATERIALS AND METHODS}

\section{a- Tested sugar beet varieties:}

Fifteen sugarbeet varieties, seven were belonging to Monogerm (Cesira, Élan, Esperanza, Hilma, Orio, Romano and Soccara) and eight varieties were belonging to Multigerm (Baraka, Gloria, Kawemira, Laser, Marathon, Oscarpoly, Raspoy and Top). All evaluated sugarbeet varieties were with different levels of susceptibility to the root-knot nematodes according to Maareg et al., 2005; Gohar and Maareg, 2009; Maareg et al., 2009 and Saleh et al., 2009.

\section{b- Field experiments:}

Percentage yield decline due to $M$. javanica was measured in 15 sugar beet varieties in 2009/ 2010 and 2010/ 2011 in field experiments. Experimental design was strip-plot in randomized complete block with four replications at $71^{\text {st }} \mathrm{km}$ Alexandria - Cairo desert road in West Nubariya region. The soil type was sandy soil containing distinctly low percentage of organic matter $(0.37 \%)$, with a $\mathrm{pH}$ of 8.05 . The average particle size distribution was $88.2 \%$ sand, $5.5 \%$ fine sand, $2.0 \%$ silt and $4.3 \%$ clay. The field was naturally infected with $M$. javanica and had been planted for sugar beet for several years before initiation of this study. The horizontal factor was sugar beet varieties and vertical factor was fumigation treatment (fumigated 
with Dazomet $98 \%$ micro granules at $150 \mathrm{~kg}_{\text {fed. }}{ }^{-1}$ the major degradate being Methyl Isothiocyanate).

Before preparation of seedbed, pre irrigation followed by deep ploughing was done for experimental area with a seven blades' chisel to improve the tilth of the seedbed and permits better mechanical incorporation of pre plant Dazomet $98 \%$ micro granules. In fumigated plots, Methyl Isothiocyanate (MITC) was broadcasted behind the seven blades' chisel averagely $30 \mathrm{~cm}$ deep, the chisel trace that containing Dazomet granules was covered and compacted with woody Crawler pooled to $90 \mathrm{hp}$ tractor to seal soil surface to have effective soil fumigation. That was done under $60 \%$ field capacity moisture at the first week of October for both studied seasons; the waiting period between application and planting was ten days. Subplots consisted of six ridges ( $50 \mathrm{~cm}$ spacing) by $3.5 \mathrm{~m}$ in length $(3 \mathrm{~m} \times 3.5 \mathrm{~m}=10.5$ $\mathrm{m}^{2}$ ) i.e. 1/400 Fed. The horizontal plots had sugar beet varieties which were planted at five seeds per $100 \mathrm{~cm}$ of ridges. All other agricultural practices for growing sugar beet were done as recommended by Sugar Crops Research Institute for newly reclaimed soils. Also, weed and insect control was according to Cooperative Extension Service guidelines. All plots were managed identically and irrigation was applied as needed.

Yield data were collected at harvest after 200 days from sowing date. Sugar beet plants of each plot were up-rooted, topped, cleaned and weighed to determine root yield in tons/ fed. Whereas, sugar yield per Feddan was estimated after taking subsamples from each plot as fully cleaned roots and sent to Nile Sugar Company Lab to determine technological characters as Pol\%, K, Na and a N (meq/ $100 \mathrm{~g}$ beet) which in turn recoverable sugar yield (ton/ fed) was deduced as described by Mohamed (2002), applying the following formulae:

1. Recoverable sugar yield (ton/ fed) $=$ roots yield (ton/ fed) $\times$ Rendement (recoverable sugar percent).

2. Rendement was deduced according to Harvey and J.V. Dutton (1993) as it is = Pol\% $-[0.29+0.343(\mathrm{~K}+\mathrm{Na})+\alpha \mathrm{N}(0.094)$, where, Pol\%, $\mathrm{K}, \mathrm{Na}$, and $\alpha$ - amino- $\mathrm{N}$ were determined as meq/ $100 \mathrm{~g}$ beet.

Percentage yield decline for roots and sugar were calculated for each replication of each variety as the difference in yield between the fumigated and nonfumigated plots divided by the yield of the fumigated plots. Data on percentage yield decline were analyzed as a randomized complete block design.

Soil samples for nematode analysis were collected from the field trials in midseason (25 January 2011 and 27 January 2012) and near harvest (4 April 2010 and 7 April 2011). Soil samples consisted of a composite of 20 soil cores collected from the two center ridges of each plot to a depth of $20 \mathrm{~cm}$ with a 2.5-cm-diameter sampling tube from the root zone.

Nematodes were extracted from $150 \mathrm{~cm}^{3}$ soil by centrifugal flotation (Jenkins, 1964). Root galling was evaluated on a 0 to 5 scale within a few days of harvest in 2010 and 2011 by digging and rating 10 root systems per plot. The scale used was as follows: $0=$ no galls; $1=1$ to 2 galls; $2=3$ to 10 galls; $3=11$ to 30 galls; $4=31$ to 100 galls; and $5=>100$ galls per root system (Maareg et al., 2005). 
Gohar, I. M. A. et al.

The relationship between yield potential and percentage yield decline caused by $M$. javanica was described and evaluated by regression analysis (Wessa, 2008). Yield potential for each variety was estimated from fumigated plots. Mean yield potential (achievable yield) and mean percentage yield decline were calculated for each variety in each season on the basis of data from the two field trials. Regressions of midseason nematode population densities and end-of-season galls number against percentage yield decline caused by $M$. javanica also were calculated. Multiple regression analysis was used to evaluate the combined effects of midseason nematode population densities and yield potential on percentage yield decline.

c- Outdoors pots experiments:

The 15 sugar beet varieties used in the field experiments also were evaluated in two outdoor pots trials for their ability to host $M$. javanica reproduction. Each trial had six replications in a randomized complete block design. Sugar beet seeds were planted into $15-\mathrm{cm}$-diameter pots filled with steam sterilized sandy soil on 1 April 2009 for $1^{\text {st }}$ season and on 21 April 2010 for $2^{\text {nd }}$ season Soil temperatures in the pots varied between 22 and $25{ }^{\circ} \mathrm{C}$ during the study. Seedlings were thinned to one plant per pot before inoculation.

Nematode eggs were collected from the heavily infected roots of eggplant (Solanum melongena. 'Black beauty') by agitating roots in $0.5 \%$ sodium hypochlorite solution for two minutes (Hussey and Barker, 1973) approximately $1 \mathrm{~h}$ before inoculation. Nematode inoculums' of $4000 \mathrm{M}$. javanica eggs per pot according to Gohar and Maareg (2009) - approximately 400 eggs $150 \mathrm{~cm}^{-3}$ soils- were added after thinning in both seasons. Inoculum was distributed into two holes (approximately $2.5 \mathrm{~cm}$ deep) and covered with soil. Pots were watered immediately following inoculation.

Sixty days after nematode inoculation, plants were harvested and number of galls root system ${ }^{-1}$ was counted. Nematode eggs root system ${ }^{-1}$ were extracted from all roots in a pot on 16 July 2010 for Trial 1 and 3 August 2011 for Trial 2 (both 60 days after inoculation). Roots were washed free of soil, cut into $5-\mathrm{cm}$ pieces, and agitated in a 1\% sodium hypochlorite solution in a 1-L flask for four minutes. Eggs were collected and rinsed with tap water on nested 150- over 25- $\mu \mathrm{m}$-pore sieves. Egg counts were subjected to a squareroot transformation to normalize the error variances before statistical analysis. Data from the two trials were analyzed separately by analysis of variance and means separation was done according to Duncan's new multiple range test $(P$ $=0.05$ ). Root galling was evaluated before egg extraction for both trials using the 0 to 5 scale described previously.

Multiple regression analysis was used to determine the combined effects of the amount of $M$. javanica reproduction and yield potential (achievable yield) on percentage yield decline caused by M. javanica. For this analysis, yield potential and yield decline means for each variety in each season were estimated from the field trials as previously described, and nematode reproduction was estimated on the basis of reproduction data from the two outdoor pots evaluations (12 observations per variety). Reproduction data were standardized as a percentage of the known susceptible sugar beet variety Hilma. 


\section{RESULTS}

\section{In field experiments:}

There were significant differences $(P \leq 0.01)$ between nematode population densities in nonfumigated plots than in fumigated plots at sugar beet midseason in both 2009/2010 and 2010/2011 seasons, (25 January 2010 and 27 January 2011, respectively). Mean midseason nematode densities in $1^{\text {st }}$ season were $536 \mathrm{M}$. javanica juveniles per $150 \mathrm{~cm}^{3}$ of soil in the nonfumigated plots and 5 in the fumigated plots. By harvest, population densities had increased to 133 per $150 \mathrm{~cm}^{3}$ in fumigated plots and 1237 per $150 \mathrm{~cm}^{3}$ in nonfumigated plots. In $2^{\text {nd }}$ season, mean midseason nematode levels were 103 in the nonfumigated plots and 13 in the fumigated plots. By harvest, population densities had increased to 335 per $150 \mathrm{~cm} 3$ in fumigated plots and 998 per $150 \mathrm{~cm} 3$ in nonfumigated plots. Root galling averaged 1.3 in fumigated plots and 3.7 in nonfumigated plots in $1^{\text {st }}$ season, and 2.1 in fumigated plots and 3.9 in nonfumigated plots in $2^{\text {nd }}$ season.

The percentage roots yield decline caused by $M$. javanica differed $(P \leq 0.05)$ among sugar beet varieties in both 2009/2010 and 2010/2011 seasons, though roots yield decline was greater in $1^{\text {st }}$ season (Table 1). Yield potential of the varieties ranged from 21.36 to $26.25 \mathrm{~kg}_{\text {ton fed }}{ }^{-1}$ in $1^{\text {st }}$ season and from 15.66 to 19.79 ton roots fed ${ }^{-1}$ in $2^{\text {nd }}$ season. Yield decline ranged from 32.2 to $46.2 \%$ in 2011 and from 26.3 to $34.5 \%$ in $2^{\text {nd }}$ season. In both seasons, the moderately resistant variety Laser suffered the lowest percentage yield decline. There was a significant year $\times$ varieties interaction, so the data could not be pooled for a combined analysis. The average percentage of roots yields loss for the two years was greater in monogerm variety $(36.5 \%)$ than in multigerm variety $(33.5 \%)$.

The same trend was observed on sugar yield potential in fumigated plots ranged in the first year from 3.0 to 4.6 tons fed $^{-1}$ and from 2.7 to 4.1 tons $\mathrm{fed}^{-1}$ in the second year i.e. it was greater in the first year than the second one (Table 2). Percentage of sugar yield decline resulted from $M$. javanica infestation was also greater in the first year than the second, whereas it ranged from 47.2 to $57.3 \%$ and from 44.9 to $51.1 \%$, respectively. There was a significant year $\times$ varieties interaction, so the data could not be pooled for a combined analysis. No variety consistently had a lower percentage yield loss than the other varieties (all of them in both tested years achieved sugar yield decline around $50 \%$ ). The average percentage of sugar yield loss for the two years was greater in monogerm variety $(52.2 \%)$ than in multigerm variety $(48.5 \%)$. Anyhow, the overall mean of percentage sugar yield decline was merely greater than it was in roots yield decline.

\section{In outdoors pots experiments:}

Nematode reproduction as total eggs produced on root system varied among tested sugar beet varieties in the two outdoor pots trials (Table 3 ). There was a significant trials $\times$ genotype interaction, so the data could not be pooled for a combined analysis. The moderately resistant Romano sugar beet variety supported the least reproduction in both trials as a monogerm variety, and the variety marathon consistently supported lower reproduction 
Gohar, I. M. A. et al.

than the most multigerm varieties. The 15 varieties tested did not all support similar levels of reproduction (only some of them) in either trial, but as indicated by the trials $\times$ varieties interaction, the relative level of reproduction supported by varieties were not consistent between trials.

Evaluation for root galling was done for the two outdoor pots trials. Galling generally was severe in the first trail and moderately in the second one but, statistically similar within the single trail among the varieties (Table 3 ). The monogerm variety Hilma had the highest mean gall rating in the study (9.3 and 4.0 for trails 1 and 2, respectively), also, the multigerm Gloria had the second highest mean gall rating (8.7 and 4.3 for the two trails, orderly), and though all other varieties had levels of galling that were similar. The moderately resistant variety Marathon suffered the least galling with average of 4.5 for the two trails. There was a significant Trials $\times$ varieties interaction, so the data could not be pooled for a combined analysis. The average root galling for the two trails was greater in first trail (7.6) than in second one (3.4).

Regression analysis based on the $2 \mathrm{yr}$ of field data revealed a linear relationship in which increasing roots yield potential was associated with increasing percentage roots yield decline (Fig. 1). Comparison of the slope and intercept values of the regression lines calculated for the 2009/2010 and 2010/2011 data verified that both the slope and intercept values were similar (LSD 0.10) for the two years, so the data were combined and a single regression was percentage roots yield decline (loss) when roots yield potential was zero (the regression intercept) was -11.01 , which is not statistically different from zero $(P=0.95)$. The combined regression predicted that percentage roots yield decline was equal to $-11.011+$ (Roots yield potential) $(2.0160)\left(P=0.0005, R^{2}=0.81\right)$.

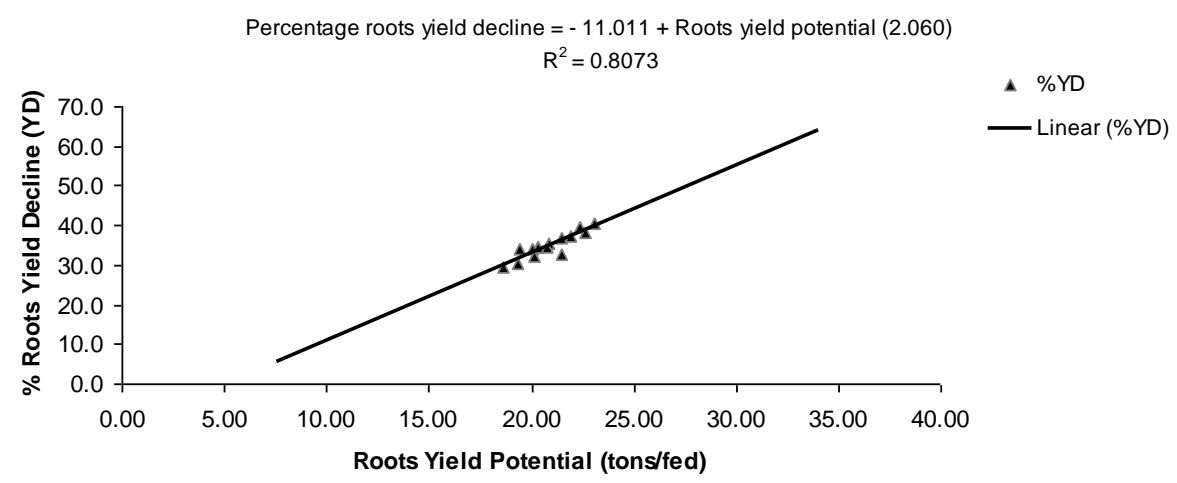

Fig. 1: The relationship between roots yield potential of sugar beet and percentage roots yield decline caused by Meloidogyne javanica at West Nubariya in 2009/2010 and 2010/2011 seasons.

Regression analysis showed that post-harvest root gall ratings were not related to percentage yield decline $(P>0.10)$ in either year or when the two years were combined. Midseason nematode population densities were 
related to percentage yield decline (Fig. 2). The calculated slope and intercept values did not differ $(P>0.10)$ between $1^{\text {st }}$ and $2^{\text {nd }}$ seasons, so the data was combined and a single regression was calculated. The combined regression predicted that percentage roots yield decline was equal to $0.1096+$ (midseason nematode levels) $(0.1097)\left(P=0.0015, R^{2}=0.996\right)$.

Multiple regression analysis revealed that yield potential $\left(P \_0.0016\right)$ and the relative amount of $M$. javanica reproduction $(P=0.07 \overline{00})$ both affected the percentage yield decline caused by $M$. javanica in a linear manner. Yield decline increased as either yield potential or nematode reproduction increased. The predicted percentage yield loss when both yield potential and nematode reproduction were zero (the regression intercept) was $-8.937 \%$, which is not different from zero $(P=0.336)$. The combined regression predicted that percentage yield decline was equal to $-8.937+$ (yield potential) $(1.8882)+($ reproduction $)(0.000997)\left(P=0.00005, R^{2}=\right.$ 0.957).

Multiple regression analysis revealed that roots yield potential $(P=$ 0.0276) and midseason $M$. javanica population levels $(P=0.0752)$ both affected the percentage roots yield decline caused by $M$. javanica in a linear manner. Root yield decline increased as either nematode levels or yield potential increased. The predicted percentage yield loss when both yield potential and nematode population levels were zero (the regression intercept) was $-1.549 \%$, which is not different from zero $(P=0.4534)$. The combined regression predicted that percentage roots yield decline was equal to -1.549 + (roots yield potential) $(0.2721)+$ (number of $M$. javanica) $(0.0808)(P=$ $\left.0.00001, R^{2}=0.997\right)$.

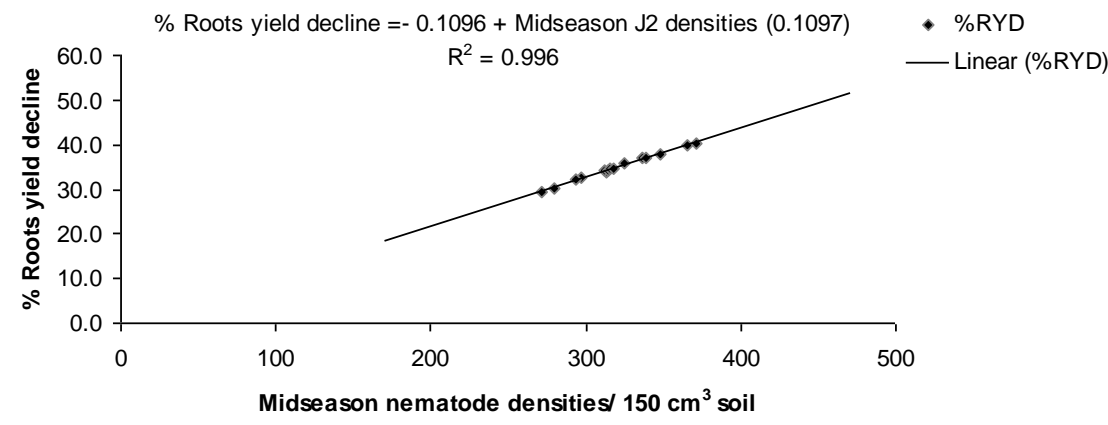

Fig. 2: The relationship Percentage roots yield decline of sugarbeet and midseason juvenile of Meloidogyne javanica at West Nubariya in 2009/2010 and 2010/2011 seasons. 
Gohar, I. M. A. et al.

Table 1: Roots yield decline caused by the root-knot nematode, Meloidogyne javanica in sugar beet varieties grown at West Nubariya Region over the two successive seasons of 2009/2010 and 2010/2011.

\begin{tabular}{|c|c|c|c|c|c|c|c|}
\hline \multirow[b]{2}{*}{ Varieties } & \multicolumn{3}{|c|}{$\begin{array}{c}\text { Roots yield (tons/fed) } \\
1^{\text {st }} \text { season }\end{array}$} & \multicolumn{3}{|c|}{$\begin{array}{c}\text { Roots yield (tons/fed) } \\
2^{\text {ndd }} \text { season }\end{array}$} & \multirow{2}{*}{$\begin{array}{c}\text { Mean } \\
\text { Yield } \\
\text { decline } \\
\% \text { Over } 2 \\
\text { seasons }\end{array}$} \\
\hline & \begin{tabular}{|l} 
In \\
fumigated \\
plots
\end{tabular} & $\ln _{\substack{\text { nonfumigated } \\
\text { plots }}}$ & Decline & \begin{tabular}{|c|} 
In \\
fumigated \\
plots
\end{tabular} & $\begin{array}{l}\text { In } \\
\text { nonfumigated } \\
\text { plots }\end{array}$ & Decline & \\
\hline \multicolumn{8}{|c|}{ 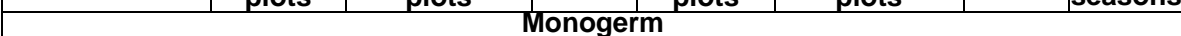 } \\
\hline Cesira & 25.22 & 13.8 & 45.4 & 19.44 & 12.8 & 34.0 & 39.7 \\
\hline Elan & 21.36 & 13.4 & 37.5 & 17.52 & 12.2 & 30.5 & 34.0 \\
\hline Esperanza & 24.68 & 14.1 & 42.7 & 18.33 & 12.6 & 31.0 & 36.9 \\
\hline Hilma & 22.21 & 13.7 & 38.3 & 17.90 & 12.5 & 30.2 & 34.3 \\
\hline Orio & 23.75 & 14.1 & 40.5 & 18.00 & 12.5 & 30.8 & 35.7 \\
\hline Romano & 22.40 & 13.8 & 38.6 & 18.24 & 12.7 & 30.2 & 34.4 \\
\hline Soccara & 26.27 & 14.1 & 46.2 & 19.79 & 13.0 & 34.5 & 40.4 \\
\hline Average & 23.70 & 13.85 & 41.31 & 18.46 & 12.61 & 31.6 & 36.5 \\
\hline \multicolumn{8}{|c|}{ Multigerm } \\
\hline Baraka & 23.44 & 14.0 & 40.3 & 17.22 & 12.2 & 29.0 & 34.7 \\
\hline Gloria & 25.14 & 14.3 & 43.2 & 18.63 & 12.8 & 31.2 & 37.2 \\
\hline Kawemira & 23.69 & 14.3 & 39.8 & 17.75 & 12.5 & 29.7 & 34.8 \\
\hline Laser & 21.53 & 14.6 & 32.2 & 15.66 & 11.5 & 26.3 & 29.3 \\
\hline Marathon & 24.78 & 15.8 & 36.1 & 18.11 & 12.8 & 29.5 & 32.8 \\
\hline Oscarpoly & 22.15 & 14.8 & 33.3 & 16.55 & 12.0 & 27.2 & 30.3 \\
\hline Raspoly & 23.12 & 14.8 & 35.9 & 17.15 & 12.3 & 28.3 & 32.1 \\
\hline Top & 26.25 & 14.6 & 44.32 & 19.00 & 13.0 & 31.7 & 38.0 \\
\hline Averaqe & 23.81 & 14.74 & 37.83 & 17.55 & 12.42 & 29.1 & 33.5 \\
\hline Overall mean & 23.8 & 14.3 & 39.6 & 18.0 & 12.5 & 30.4 & 35.0 \\
\hline L S D at $P \leq 0.05$ & 2.89 & 1.73 & 4.81 & 2.17 & 1.52 & 3.69 & \\
\hline
\end{tabular}

- Values are averages of four replicates

- Soil treatment was at $150 \mathrm{~kg} \mathrm{fed}^{-1}$ of Dazomet $98 \%$ micro granules

- Means different according to Duncan's new multiple range test $(P=0.05)$.

Table 2. Sugar yield decline caused by the roots-knot nematode, Meloidogyne javanica in sugar beet varieties grown at West Nubariya Region over the two successive seasons of 2009/2010 and 2010/2011.

\begin{tabular}{|c|c|c|c|c|c|c|c|}
\hline \multirow[b]{2}{*}{ Varieties } & \multicolumn{3}{|c|}{$\begin{array}{c}\text { sugar yield (tons/fed) } \\
1^{\text {st }} \text { season }\end{array}$} & \multicolumn{3}{|c|}{$\begin{array}{c}\text { sugar yield (tons/fed) } \\
2^{\text {yld }} \text { season }\end{array}$} & \multirow{2}{*}{\begin{tabular}{|c|} 
Mean \\
Yield \\
decline \\
$\%$ Over 2 \\
seasons
\end{tabular}} \\
\hline & \begin{tabular}{|c|} 
In \\
fumigated \\
plots
\end{tabular} & $\underset{\substack{\text { In } \\
\text { plots }}}{\text { nonfumigated }}$ & Decline & \begin{tabular}{|c|} 
In \\
fumigated \\
plots
\end{tabular} & $\underset{\substack{\text { In } \\
\text { plots }}}{\text { nonfigated }}$ & Decline & \\
\hline \multicolumn{8}{|c|}{ Monogerm } \\
\hline Cesira & 4.3 & 1.9 & 55.3 & 4.1 & 2.0 & 51.1 & 53.2 \\
\hline Elan & 3.5 & 1.8 & 47.2 & 3.0 & 1.6 & 47.1 & 47.2 \\
\hline Esperanza & 4.2 & 2.1 & 51.1 & 3.7 & 1.9 & 49.3 & 50.2 \\
\hline Hilma & 3.7 & 1.9 & 49.9 & 3.3 & 1.7 & 48.1 & 49.0 \\
\hline Orio & 4.0 & 1.9 & 52.3 & 3.5 & 1.7 & 50.2 & 51.3 \\
\hline Romano & 3.8 & 1.9 & 50.0 & 3.3 & 1.7 & 47.9 & 49.0 \\
\hline Soccara & 4.4 & 1.9 & 56.3 & 3.9 & 1.9 & 50.3 & 53.3 \\
\hline Average & 4.0 & 1.9 & 51.7 & 3.5 & 1.8 & 49.1 & 50.4 \\
\hline \multicolumn{8}{|c|}{ Multigerm } \\
\hline Baraka & 3.2 & 1.6 & 50.6 & 2.7 & 1.5 & 45.1 & 47.9 \\
\hline Gloria & 3.7 & 1.8 & 51.7 & 3.0 & 1.6 & 46.9 & 49.3 \\
\hline Kawemira & 4.1 & 1.9 & 53.5 & 3.5 & 1.8 & 49.0 & 51.3 \\
\hline Laser & 3.0 & 1.5 & 48.7 & 2.9 & 1.5 & 47.0 & 47.9 \\
\hline Marathon & 4.3 & 1.9 & 55.0 & 3.5 & 1.7 & 50.3 & 52.7 \\
\hline Oscarpoly & 3.3 & 1.6 & 50.8 & 2.7 & 1.5 & 44.9 & 47.9 \\
\hline Raspoly & 3.5 & 1.7 & 51.5 & 3.0 & 1.6 & 47.0 & 49.3 \\
\hline Top & 4.6 & 2.0 & 57.3 & 3.7 & 1.8 & 50.1 & 53.7 \\
\hline Average & 3.8 & 1.8 & 52.6 & 3.2 & 1.7 & 47.9 & 50.3 \\
\hline Overall mean & 3.9 & 1.8 & 52.2 & 3.4 & 1.7 & 48.5 & 50.4 \\
\hline$L S D$ at $P \leq 0.05$ & 0.47 & 0.22 & 6.34 & 0.41 & 0.21 & 5.89 & \\
\hline
\end{tabular}

- Values are averages of four replicates.

- Soil treatment was at $150 \mathrm{~kg} \mathrm{fed}^{-1}$ of Dazomet $98 \%$ micro granules

- Means different according to Duncan's new multiple range test $(P=0.05)$. 
Table 3. Reproduction of roots-knot nematode, Meloidogyne javanica as total produced eggs on sugar beet varieties in outdoors pots studies.

\begin{tabular}{|c|c|c|c|c|c|}
\hline \multirow{2}{*}{ Varieties } & \multicolumn{2}{|c|}{$1^{\text {st }}$ season } & \multicolumn{2}{|c|}{$2^{\text {nd }}$ season } & \multirow{2}{*}{$\begin{array}{c}\text { Mean gall } \\
\text { index } \\
\text { Over } 2 \text { Trials }\end{array}$} \\
\hline & Total eggs & Gall index & Total eggs & Gall index & \\
\hline \multicolumn{6}{|c|}{ Monogerm } \\
\hline Cesira & $9988 b$ & 8.3 & 3919a & 3.3 & 5.8 \\
\hline Élan & $8998 b$ & 8.0 & $3529 b$ & 3.3 & 5.7 \\
\hline Esperanza & $9982 b$ & 7.7 & $3900 a$ & 3.1 & 5.4 \\
\hline Hilma & $10336 a$ & 9.3 & $4056 a$ & 4.0 & 6.7 \\
\hline Orio & $8335 b c$ & 7.5 & $3275 b c$ & 3.0 & 5.3 \\
\hline Romano & $8113 b c$ & 7.3 & $3187 b c$ & 2.7 & 5.0 \\
\hline Soccara & $9587 b$ & 7.9 & $3767 a b$ & 3.0 & 5.5 \\
\hline Average & $9334 b$ & 7.9 & 3662 & 3.1 & 5.6 \\
\hline \multicolumn{6}{|c|}{ Multigerm } \\
\hline Baraka & $9954 b$ & 7.7 & $3919 a$ & 3.0 & 5.4 \\
\hline Gloria & $11470 a$ & 8.7 & $4509 a$ & 4.3 & 6.5 \\
\hline Kawemira & $10004 a$ & 8.5 & $4060 a$ & 4.0 & 6.3 \\
\hline Laser & $9003 b c$ & 7.0 & $3653 b$ & 3.0 & 5.0 \\
\hline Marathon & 7989bcd & 6.3 & $3241 b c$ & 2.7 & 4.5 \\
\hline Oscarpoly & $9295 b$ & 7.3 & $3635 b$ & 3.0 & 5.2 \\
\hline Raspoly & $8958 b c$ & 6.9 & $3505 b$ & 3.0 & 5.0 \\
\hline Top & $10238 a$ & 8.2 & $4000 a$ & 3.7 & 6.0 \\
\hline Average & 9565 & 7.6 & $3800 a$ & 3.4 & 5.5 \\
\hline Overall mean & 9450 & 7.7 & 3731 & 3.3 & 5.5 \\
\hline$L S D$ at $P \leq 0.05$ & & 0.94 & & 0.4 & \\
\hline
\end{tabular}

- Data presented are actual number of eggs, but statistical analysis was performed on square-root transformed data. Values in the same column followed by the same letter are not significantly different according to Duncan's new multiple range test $(P=0.05)$.

- Data presented are means of 12 replications (six replicates / trial) combined across harvest dates (both 60 days after inoculation).

- Gall index was on a scale of 0 to 5 , where $0=$ no galls; $1=1$ to $2 ; 2=3$ to $10 ; 3=11$ to 30 ; $4=31$ to 100 ; and $5=$ more than 100 galls.

Also, estimated regression equation by multiple regression for sugar yield potential $(P=0.00027)$ and midseason $M$. javanica levels $(P=0.0752)$ both affected the percentage sugar yield decline caused by $M$. javanica in linear manner. Sugar yield decline increased as either nematodes levels or sugar yield potential increased. The predicted percentage sugar yield loss when both yield potential and nematode population levels were zero (the regression intercept) was $30.094 \%$, which is not different from zero ( $P=$ $0.0001)$. The combined regression predicted that percentage sugar yield decline was equal to $=+30.0941+$ (potential sugar yield) $4.6457+0.0065$ (number of $M$. javanica).

\section{DISCUSSION}

The objective of this study was to determine if any of the fifteen tested sugar beet varieties are more tolerant than others for parasitism by $M$. javanica. Though significant levels of tolerance were measured in our study, by relating sugar beet potential yields (roots and sugar) with percentage yield 
Gohar, I. M. A. et al.

decline and confirm this by multiple regression analysis with nematode midseason densities and nematode reproduction as number of eggs on root system on the tested sugar beet varieties, tolerance was not consistently related to specific varieties in the absence of nematode resistance. The moderately resistant germplasm consistently suffered the least yield decline in the study, but the level of yield decline for each of the susceptible cultivars was inconsistent. Sugar beet varieties differ in yield potential and qualities. Some of the observed differences in roots yield and quality among varieties may have been the result of differences in yield potential among cultivars (Stevens et al. 2008 and Tsialtas and Maslaris, 2012)

The relationship in this study between percentage yield decline and midseason nematode levels is consistent with the assumption that yields generally should decrease as nematode population levels increase and as stated by Gohar and Maareg (2005) and Maareg et al. (2009). It is notable that the relationship between yield potential and percentage yield decline for roots and sugar is significant even when the effect of nematode population density is considered. Regression slopes and intercepts were similar between years despite differences in environment, yield potential, and percentage yield decline. This also on the same line with the findings of Gohar and Maareg (2005) and Maareg et al. (2009), they found that the rate of decrease or loss \% in sugar yield was greater than in the root yield.

The term yield potential has been defined as "the yield of a variety when grown in environments to which yield of a variety when grown in environments to which it is adapted; with nutrients and water non-limiting; and with pests, diseases, weeds, lodging and other stresses effectively controlled" (Evans and Fischer, 1999). When sugar beet is parasitized by M. javanica, yields will be below the yield potential. A generic damage function that relates the degree of yield decline to nematode population density is:

$$
y=\frac{\text { yield }_{\mathrm{p}}-\text { yield }_{\min }}{\text { yield }_{\max }-\text { yield }_{\min }}
$$

Where $y=$ the relative yield (between 0.0 and 1.0) at nematode density $P$; yield $P=$ yield at nematode density $P$; yield $d_{\min }=$ a minimum yield that will be achieved even at the highest nematode densities; and yield $\mathrm{max}_{\mathrm{m}}=\mathrm{a}$ maximum yield achieved in the absence of nematodes (Seinhorst, 1965).Yield $\mathrm{max}_{\max }$ in Seinhorst's equation would be the crop's yield potential when other limiting factors are effectively minimized. The model, which is not specific to any crop or any nematode, helps explain the relationship between nematode population density and yield loss. For a specific nematode population density, the relative yield will decrease if the yield potential increases. This predicts that nematode parasitism will decrease yield by a greater percentage as yield potential increases, which was predictable in our study.

The relationship between the percentage yield decline caused by nematodes and yield potential has not been examined previously in sugar beet crop. Some studies adopted for sugar beet by Gohar and Maareg, 2005 
to estimate tolerance limit for sugar beet that infected with root knot nematodes by performing analysis using Seinhorst (1982) damage function as the model to relate yields to nematode densities in order to estimate tolerance limit " $T$ " (the nematode density below which no detectable loss in yield occurs i.e. Potential yield) could be calculated according to the equation: $Y=m=(1-m)^{*} 0.95(P / T)^{-1}$. As well, damage or loss levels of sugar beet root yield were compared using chi-square $\left(\mathbf{X}^{2}\right)$ by analyzing frequency data for latency data, i.e., to point out Economic injury level (EIL) which is defined as the pest population that inflicts crop damage greater than the cost of control measures (Rex Dufour, 2001 and Gohar and Maareg, 2005). From this point "cost of control measures", it can be associated with this study which denoted that there is a great relation between yield potential and percentage yield decline as the first increases the second increases, i.e. sugar beet varieties with great yield potential have a great percentage yield decline in the root knot nematode infested fields could be avoided "avoidable loss" by sound control measures economically, because the value of yield portion that will be protected will be superior or at least equal the cost of control measure plus it will minimize nematode population in the succeeding crop(s).

Yield potential can be increased through breeding and selection for genotypes that allow the plants to be more responsive to inputs and exploit favorable growing conditions (Fasoula and Fasoula, 2002; Pala et al., 2004 and Tokatlidis and Koutroubas, 2004). Although genotypes usually are evaluated under a range of conditions, cultivars often are selected on the basis of outstanding performance in favorable environments (Calhoun et al., 1994). Meloidogyne spp. infection impairs root function and limits growth of the root system, which reduces a plant's ability to exploit favorable environments fully. If nematode parasitism inhibits exploitation of favorable growing conditions, then the percentage yield decline would be greater for input-responsive genotypes (which have higher yield potentials) than for genotypes that were less capable of exploiting favorable conditions.

High yield under ideal conditions, which is one definition of yield potential (Evans and Fischer, 1999), is often one of the primary goals of plant breeding. Unfortunately, increasing yield potential increases the percent age yield decline in sugar beet caused by $M$. javanica. An increase in relative damage as yield potential increases probably also occurs in other crops with other nematodes. Therefore, because the absolute and percentage losses to nematodes increase as yield potential increases, nematode management becomes increasingly important and beneficial.

\section{Conclusion}

From the study it can be concluded that:

- Tolerance is not consistently related to specific sugar beet varieties in the absence of nematode resistance: susceptible varieties did not consistently express tolerance, but moderately resistant varieties did. Thus, it appears unlikely that sugar beet variety selection for tolerance to $M$. javanica can be utilized to minimize yield decline. 
Gohar, I. M. A. et al.

- The absolute and percentage losses to nematodes increase as yield potential increases; nematode management becomes increasingly important and beneficial in sugar beet i.e. sugar beet varieties with great yield potential have a great percentage yield decline in the root knot nematode infested fields could be avoided "avoidable loss" by sound control measures economically, because the value of yield portion that will be protected will be superior or at least equal the cost of control measure.

- The moderately resistant sugar beet varieties, Laser, Romano and Marathon suffered the lowest percentage yield decline and supported the least reproduction in the study so they can be used in the contaminated fields with root-knot nematode through an integrated control measures to maintain good production for sugar beet in such area.

\section{REFERENCES}

Calhoun, D.S.; G. Gebeyehu; A. Miranda; S. Rajaram, and M. Van Ginkel (1994). Choosing evaluation environments to increase wheat grain yield under drought conditions. Crop Sci., 34:673-678.

Duncan, D. B. (1955). Multiple range and multiple $F$ tests. Biometrics 11:142.

Evans, L.T. and R.A. Fischer (1999). Yield potential: Its definition measurement, and significance. Crop Sci., 39:1544-1551.

Fasoula, V.A. and D.A. Fasoula (2002). Principles underlying genetic improvement for high and stable crop yield potential. Field Crops Res., 75:191-209.

Gohar, I.M.A. and M.F. Maareg (2009). Effect of inoculum level, type, plant age and assessment date on evaluating sugar beet resistance methods for root-knot nematode, Meloidogyne incognita. J. Agric. Sci. Mansoura Univ., 34 (5): 5401 - 5419.

Gohar, I.M.A. and M.F. Maareg (2005). Relationship between crop losses and initial population densities of root-knot nematode, Meloidogyne in soil of Sugar beet grown in West Nubariya district. Egypt. J. Agric. Res., 83 (4): 1315-1328.

Harvey C.W. and J.V. Dutton (1993). Root quality and processing. Pp.571 617. in sugar beet crop: Science into practice. Edited by D.A. Cook and Scott. Published, 1993 by Chapman \& Hall, ISBN,0412 -25132.

Hussey, R.S. and K.R. Barker (1973). A comparison of methods of collecting inocula or Meloidogyne spp., including a new technique. Plant Dis. Rep., 57:1025-1028.

Jenkins, W.R. (1964). A rapid centrifugal flotation technique for separating nematodes from soil. Plant Dis. Rep., 48:692.

Maareg M. F; I. M.A. Gohar and A.M. Abdel Aal (2005). Susceptibility of twenty one sugar beet varieties to the root-knot nematode, Meloidogyne incognita at West Nubariya District. . Egypt. J. Agric. Res., 83 (2): 789- 801. 
Maareg M. F; A. El-Gindi; Mona, E. El-Shalaby and Abeer, S. Yassin (2009). Evaluation of certain sugar beet varieties for their productivity and susceptibility to Root-knot nematode, Meloidogyne javanica. J. Agric. Sci., Mansoura Univ., Vol. 34 (6) : 6851- 6861.

Mohamed, H.F. (2002). Chemical and technological studies on sugar beet. Ph.D. Thesis, Fac. Agric., Minia Univ., Egypt. Pp135.

Pala, M.; J. Ryan; A. Mazid; O. Abdallah and M. Nachit (2004). Wheat farming in Syria: An approach to economic transformation and sustainability. Renew. Agric. Food Syst., 19:30-34.

Rex Dufour (2001). Biointensive integrated pest management (IPM)- Part one- Fundamentals of sustainable agriculture. publication of ATTRA National Sustainable Agriculture Information Service. pp: 52.

Saleh, M.S.; A.K. EL-Sayed; I.M.A. Gohar and Nancy A. Abo Ollo (2009). Evaluation of twenty seven sugar beet genotypes for resistance to root-knot nematode (Meloidogyne javanica). Alex. Sci. Exch., 30, (2): 289-298.

Seinhorst, J. W. (1982). The relationship in field experiments between population density of Globodera rostochiensis before planting potatoes and yield of potato tubers. Nematologica, 28: 277- 284.

Seinhorst, J.W. (1965). The relation between nematode density and damage to plants. Nematologica, 11:137-154.

Stevens W. B.;R. D. Violett; S. A. Skalsky and A.O. Mesbah. (2008). Response of Eight Sugarbeet Varieties to Increasing Nitrogen Application: I. Root, Sucrose, and Top Yield. Journal of Sugar Beet Research Vol.(3 \& 4): 65- 83.

Tokatlidis, I.S. and S.D. Koutroubas (2004).Areview of maize hybrids' dependence on high plant populations and its implications for crop yield stability. Field Crops Res., 88:103-114.

Tsialtas J. T. and N. Maslaris (2012). Leaf physiological traits and its relation with sugar beet cultivar success in two contrasting environments. International Journal of Plant Production, 6 (1): 15-36.

Wessa, P. (2008). Multiple Regression (v1.0.26) in Free Statistics Software (v1.1.23-r7), Office for Research Development and Education, URL http://www.wessa.net/rwasp_multipleregression.wasp/

YU, M. H. (2003). Development of Root-knot nematode resistant sugar beet varieties. $\quad 1^{\text {st }}$ joint IIRB-ASSBT Congress, 26"'Feb.-1 March 2003, San Antonio (USA) 763-765. 
Gohar, I. M. A. et al.

العلاقة بين غلة المحصول ونسبة الإنخفاض فيه التي تحدثها نيماتودا تعقد الجذور

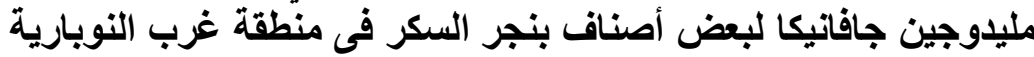

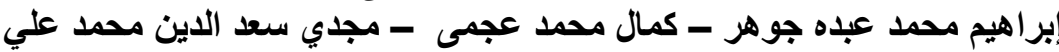

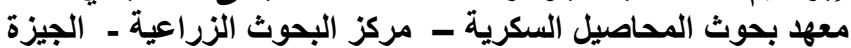

أجريت أربع تجارب اثنتين منهم حقلية والأخرياتان في الأصص في الهو اء الطلق وذلك لتقيجيم

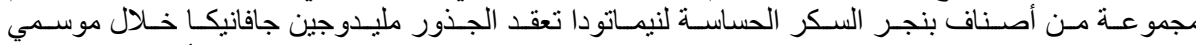

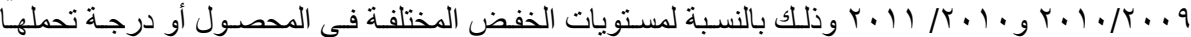

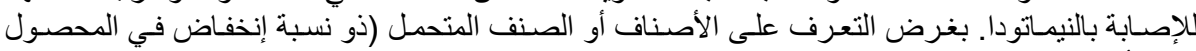

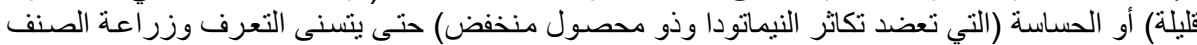

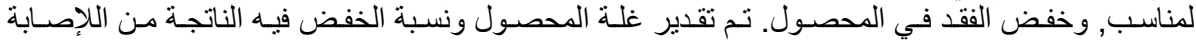

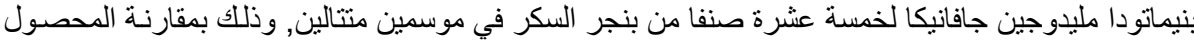

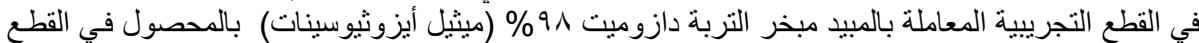

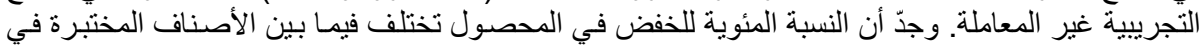

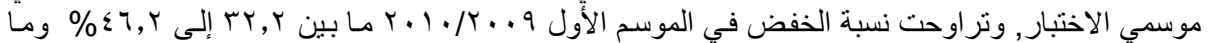

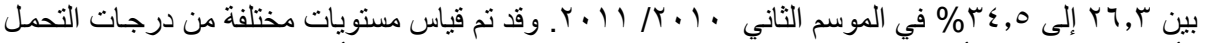

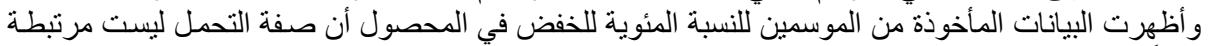

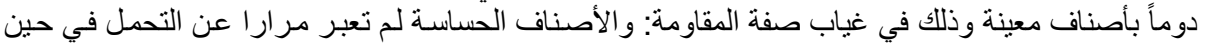

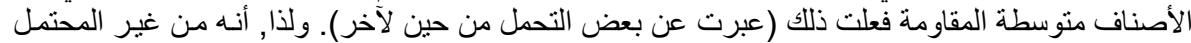

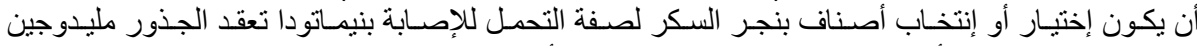

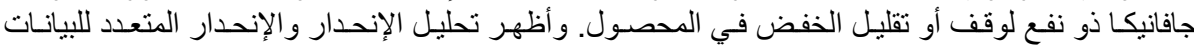

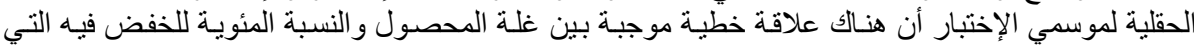

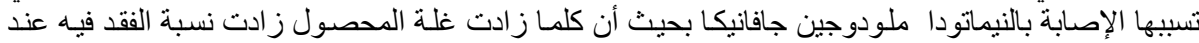

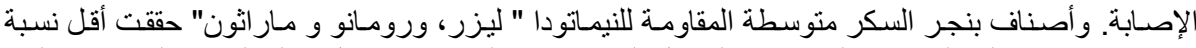

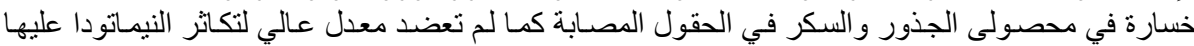

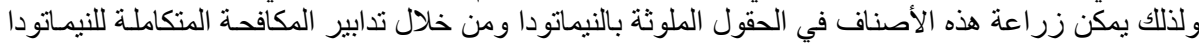

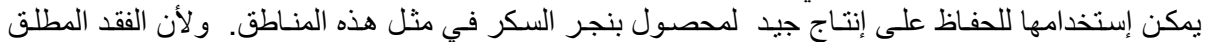

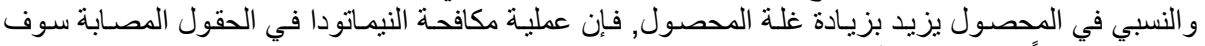
تكون مهمة جداً وذو فائدة على نحو متز ايد.

كلية الزراعة - جامعة المنصورة

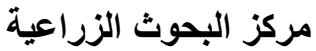

قام بتحكيم البحث

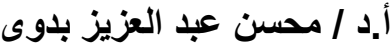

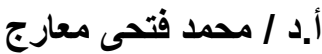

